\title{
Angiotensin-I Converting Enzyme Polymorphism and Diabetic Nephropathy in North India
}

\author{
Ajay Kumar, Kapil Mohindru and P.K. Sehajpal* \\ Department of Molecular Biology and Biochemistry, Guru Nanak Dev University, \\ Amritsar, Punjab, India
}

KEYWORDS ACE; I/D polymorphism; diabetic nephropathy; hemodialysis; North Indian population

\begin{abstract}
Diabetic nephropathy represents a major complication in patients with either type I or type II diabetes. The contribution of a $287 \mathrm{bp}$ insertion/deletion (I/D) polymorphism of the gene encoding angiotensin-I converting enzyme (ACE) has been investigated and the deletion type is documented to be a risk factor in the development of this disease. The present study was designed to determine the relationship between this polymorphism and the risk of developing advanced form of diabetic nephropathy (end stage renal disease) in type II diabetic patients from North India, known to have a high incidence of diabetes and hypertension. Polymerase chain reaction was employed to genotype the DNA isolated from peripheral blood of age and sex matched 117 subjects (59 diabetic nephropathy patients and 58 normal healthy controls). All the subjects, identified as DD, were reconfirmed with an insertionspecific primer. There was no significant difference in the distribution of DD, ID and II genotypes between diabetic nephropathy $(10,32,17)$ and normal healthy subjects $(9,33,16)$, respectively. The D allele frequencies within patient $(0.441)$ and control $(0.440)$ populations were very similar. The findings of the present study strongly suggest that I/D polymorphism of ACE gene is not implicated in the diabetic nephropathy of North Indian patients.
\end{abstract}

\section{INTRODUCTION}

Diabetic nephropathy is a leading cause of end stage renal disease (ESRD) worldwide and the number of patients needing dialysis or kidney transplantation is increasing steadily (Marshall 2004). Genetic predisposition studies suggest a potential role of genetic factors in the pathogenesis of diabetic nephropathy and the gene encoding angiotensin-I converting enzyme (ACE) is a potential candidate gene in its etiology. ACE, a potent vasoconstrictor, catalyzes the conversion of angiotensin I to angiotensin II. It also inactivates bradykinin, a vasodilator, by bringing about its proteolysis (Crisan et al. 2000). ACE gene has been described with an insertion/ deletion polymorphism (I/D) of a $287 \mathrm{bp} \mathrm{Alu}$ repetitive sequence in intron 16 (Rigat et al. 1992) leading to three genotypes, DD and II homozygotes and ID heterozygote. The mean plasma/serum ACE level in the DD subjects is reported to be approximately double that of II subjects, with ID subjects having intermediate values (Rigat et al. 1990; Pasha et al. 2002). In a

*Corresponding author: Dr. P.K. Sehajpal, Professor Department of Molecular Biology and Biochemistry, Guru Nanak Dev University, Amritsar-143 005, India. Telephone: +919417510674

Fax: +91 1832258820

E-mail: sehajpalpk@yahoo.com pioneering study, Marre et al. (1994) proposed a protective effect of the II genotype against the development of diabetic nephropathy in insulindependent diabetes mellitus. Thereafter, a sizeable number of association studies have investigated the possible role of ACE I/D polymorphism in the pathophysiology of diabetic nephropathy and most of them have recorded association of the $\mathrm{D}$ allele as a risk factor $(\mathrm{Ng}$ et al. 2005). The Punjabi population from North India is a unique population with a very high incidence of diabetes and hypertension (Gupta et al. 2004). Although, the precise number of patients with ESRD on hemodialysis in India is not known due to the lack of national registries but it is anticipated that around 100,000 patients are added each year to a large group of existing cohort (Sakhuja et al. 2003). It is important to mention that these are conservative estimates as a vast majority of poor patients who can't afford the high cost of renal replacement therapies go unnoticed. The present study was designed to determine the role of ACE polymorphism in Punjabi type II diabetic patients with advanced form of nephropathy undergoing hemodialysis.

\section{MATERIAL AND METHOD}

Study Population: Diabetic nephropathy diagnosis was based on physician's recommen- 
dations. Only type II diabetic patients on hemodialysis with advanced irreversible renal failure were selected for the present study. Information related to name, age, sex, family history of the patients was recorded. Informed consent was taken from all the individuals participating in the study. A total of 117 blood samples were collected, in disodium-EDTA, of which 59 samples were from diabetic nephropathy patients visiting Ram Saran Dass Kishori Lal Charitable Trust Hospital, Amritsar, Guru Nanak Dev Hospital, Amritsar and Kidney Hospital, Jalandhar. The rest 58 were age and sex matched normal healthy controls with no history of renal disease, diabetes mellitus and hypertension.

Genotyping ACE I/D polymorphism: DNA was extracted from collected blood samples by modified inorganic method as described by Miller et al. (Miller et al. 1988) and quantified following standard spectrophotometric analysis. Polymerase chain reaction was used to study I/ D polymorphism of ACE gene using the published primers (Rigat et al. 1992), flanking a 287 bp insertion sequence. The optimized reaction conditions consisted of $40 \mathrm{ng}$ of genomic DNA in a reaction volume of $30 \mu \mathrm{l}$ containing $0.16 \mu \mathrm{M}$ of each primer, $30 \mu \mathrm{M}$ of each dNTP, $10 \mu \mathrm{M}$ Tris-HCl (pH 9.0), $1.5 \mu \mathrm{M} \mathrm{MgCl}_{2}, 50$ $\mu \mathrm{M} \mathrm{KCl}, 0.01 \%$ gelatin and $0.3 \mathrm{U}$ of Taq DNA polymerase (Bangalore Genei, Bangalore). Amplification was carried out for 35 cycles, each cycle consisting of denaturation at $94^{\circ} \mathrm{C}$ for $30 \mathrm{~s}$, annealing at $58^{\circ} \mathrm{C}$ for $20 \mathrm{~s}$, extension at $72^{\circ} \mathrm{C}$ for $20 \mathrm{~s}$ and finally a $3 \mathrm{~min}$ extension at $72^{\circ} \mathrm{C}$. The PCR products were analyzed in $2 \%$ agarose gel and visualized following ethidium bromide staining.

All samples, identified as DD after initial amplification, were reconfirmed with an insertionspecific primer pair, (forward primer 5' GCCACTACGCCCGGCTAAT-3'; reverse primer 5'-GATGTGGCCATCACATTCGTCAGAT-3'). The reaction conditions and amplification parameters for this confirmatory reaction were the same as stated above. Known controls of each genotype were included with each set of samples for the ACE I/D polymorphism.

Statistical Analysis: Allele frequencies between the diabetic nephropathy and normal healthy control populations were compared using $2 \times 2$ contingency tables and chi-squared $\left(\chi^{2}\right)$ statistics. Statistical significance was defined at the standard 5\% level.

\section{RESULTS}

The DNA samples from 59 diabetic nephropathy and 58 normal healthy controls were amplified for I/D polymorphism in the ACE gene and analyzed. Figure 1 represents the PCR products of 190 and $490 \mathrm{bp}$ indicating the presence of deletion (DD) and insertion (II) genotype, respectively. The preferential amplification of the D allele and inefficiency of the amplification of I allele may result in the

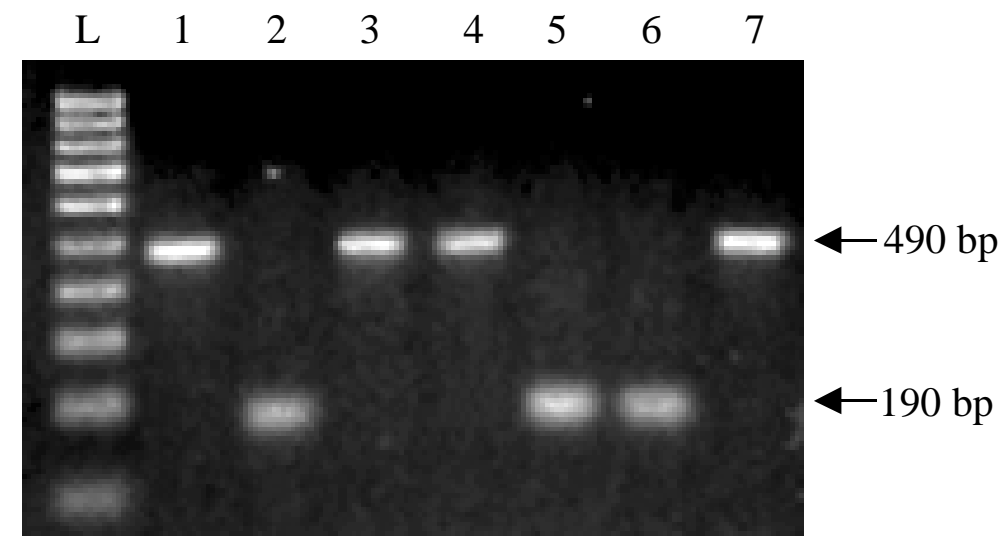

Fig. 1. Agarose gel electrophoresis stained with ethidium bromide, showing the initial amplification for ACE I/D polymorphism. Lane $L$ represents the 100 bp ladder. The II genotype for I allele was identified by the presence of single 490 bp product (Lanes 1, 3, 4 and 7). The DD genotype for D allele was identified by the presence of a single $190 \mathrm{bp}$ product (Lanes 2,5 and 6). The DD homozygotes were reconfirmed with insertion specific primer pair to avoid mistyping as ID heterozygotes. 
mistyping of ID heterozygotes as DD homozygotes. Therefore, in order to increase the specificity of DD genotyping, all samples, identified as DD after initial amplification were reconfirmed with an insertion-specific primer pair, as mentioned in material and method section. The presence of insertion sequence was revealed by the amplification of a $275 \mathrm{bp}$ fragment, while DD homozygotes failed to amplify due to the lack of annealing site (Fig. 2)

Table 1 shows the distribution of ACE genotypes in diabetic nephropathy patients and normal controls. The frequency of D allele and DD genotype was only marginally higher in

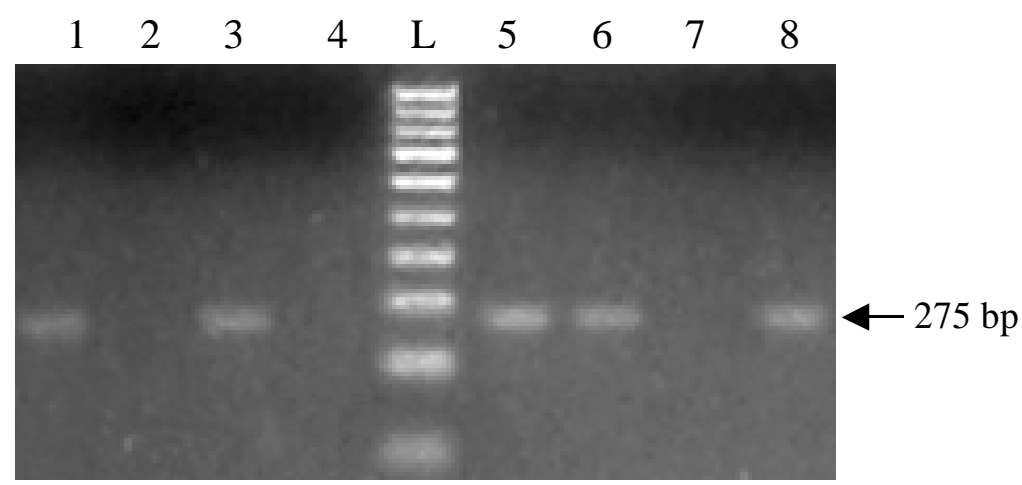

Fig. 2. Agarose gel electrophoresis of PCR products, using insertion specific primer pair, of individuals labeled as DD homozygotes following initial amplification. Absence of a product in the lanes 2,4 and 7 confirms the presence of DD genotype. Heterozygous individuals (ID genotypes) were confirmed by the presence of a single 275 bp product (Lanes 1, 3, 5, 6 and 8). Lane $L$ represents the 100 bp ladder.

Table 1: Distribution of the genotype and allele frequencies in the study groups for the angiotensin converting enzyme (ACE) I/D polymorphism.

\begin{tabular}{lrrrrrrr}
\hline Population & \multicolumn{2}{c}{ Genotype frequencies (Percentage) } & & \multicolumn{2}{c}{ Allele frequencies } \\
\cline { 2 - 3 }$(n)$ & \multicolumn{1}{c}{ DD } & $I D$ & \multicolumn{1}{c}{$I I$} & & D allele & I allele \\
\hline Diabetic nephropathy (59) & $10(17.0 \%)$ & $32(54.2 \%)$ & $17(28.8 \%)$ & & 0.441 & 0.559 \\
Normal controls (58) & $9(15.5 \%)$ & $33(56.9 \%)$ & $16(27.6 \%)$ & & 0.44 & 0.56 \\
\hline
\end{tabular}

$\dot{\div}^{2}$ based on allele frequency [degrees of freedom $(\mathrm{df})=1$ ], (Diabetic nephropathy Vs Controls) $=0.00025$; $P=1.000$

Table 2: The genotypic distribution and allele frequencies of the ACE I/D polymorphism in different populations of the world.

\begin{tabular}{|c|c|c|c|c|c|c|}
\hline \multirow{2}{*}{$\begin{array}{l}\text { Population } \\
\text { Studied (n) }\end{array}$} & \multicolumn{3}{|c|}{ Genotype distribution } & \multicolumn{2}{|c|}{ Frequencies } & \multirow[t]{2}{*}{ Reference } \\
\hline & $D D$ & $I D$ & II & $D$ allele & I allele & \\
\hline North Indian (58) & 9 & 33 & 16 & 0.44 & 0.56 & Present Study \\
\hline \multicolumn{7}{|l|}{ Caucasians: } \\
\hline French (157) & 48 & 69 & 40 & 0.525 & 0.475 & Marre et al. (1997) \\
\hline Czech (302) & 87 & 150 & 65 & 0.536 & 0.464 & Hubacek et al. (2000) \\
\hline Denmark (190) & 67 & 77 & 46 & 0.555 & 0.445 & Tarnow et al. (1995) \\
\hline UK (166) & 55 & 79 & 32 & 0.569 & 0.431 & Chowdhury et al. (1996) \\
\hline German (347) & 131 & 154 & 62 & 0.599 & 0.401 & Schmidt et al. (1997) \\
\hline Boston (77) & 16 & 41 & 20 & 0.474 & 0.526 & Doria et al. (1994) \\
\hline London (85) & 24 & 37 & 24 & 0.5 & 0.5 & Powrie et al. (1994) \\
\hline \multicolumn{7}{|l|}{ Asians: } \\
\hline Japanese (1730) & 325 & 734 & 671 & 0.4 & 0.6 & Tamaki et al. (2002) \\
\hline Chinese (1183) & 128 & 496 & 559 & 0.318 & 0.682 & Wang et al. (2005) \\
\hline Korean (107) & 17 & 41 & 49 & 0.351 & 0.649 & Oh et al. (1996) \\
\hline Tibetan (123) & 15 & 60 & 48 & 0.366 & 0.634 & Gesang et al. (2002) \\
\hline Taiwanese (263) & 24 & 106 & 133 & 0.293 & 0.707 & Hsieh et al. (2000) \\
\hline Turkish (37) & 10 & 22 & 5 & 0.57 & 0.43 & Ergen et al. (2004) \\
\hline
\end{tabular}


diabetic nephropathy patients as compared to the normal controls. The observed and expected genotypic frequencies were in Hardy-Weinberg Equilibrium.

\section{DISCUSSION}

Renal failure is an outcome of complex pathophysiological process resulting from multiple etiologies with contribution from both genetic and environmental factors. The factors that initiate ESRD in patients remain unknown, although diabetes mellitus and hypertension are known important risk factors responsible for the occurrence of this irreversible disease. Consequently, a marked ethnic difference in the risk of developing ESRD exists and believed that genetic factors are likely to be responsible for such differences (Freedman et al. 1997).

A large variation abounds in the frequencies of ACE I/D polymorphism in different ethnic groups (Table 2). It is evident from this table that the D allele frequency of our controls was intermediate to most reported Caucasian (Marre et al. 1997; Hubacek et al. 2000; Tarnow et al. 1995; Chowdhury et al. 1996; Schmidt et al. 1997) and Asian (Hsieh et al. 2000; Wang et al. 2005; Tamaki et al. 2002; Oh et al. 1996; Gesang et al. 2002; Ergen et al. 2004) populations. However, two Caucasian (Doria et al. 1994; Powrie et al. 1994) and an Asian (Tamaki et al. 2002) population are reported to have comparable allele frequencies.

The findings of $\mathrm{Ng}$ et al. in their metaanalyses, encompassing studies conducted between 1994 and 2004, revealed the association of $\mathrm{D}$ allele with the risk of having diabetic nephropathy in 14,727 patients from different geographical regions of the world. They further observed that the association was most marked among the Asian type II diabetic nephropathy patients while the Caucasians with the same etiology showed the least association. However, exceptions to such association have also been reported (Oh et al. 1996; Ergen et al. 2004).

People from the Indian subcontinent are at an increased risk of developing diabetes with the incidence among the North Indian population of Punjab being exceptionally high (Gupta et al. 2004). In a recent report, Pasha et al. studied the incidence of ACE polymorphism in different ethnic groups of India. The D allele frequencies in the five population groups from
Punjab, Harayana, Himachal Pradesh, Assam and Uttaranchal were $0.511,0.450,0.433,0.423$ and 0.409 , respectively. Of the five groups only the population from Punjab showed marginally high number of DD homozygotes over the II homozygotes. The failure to find statistically significant differences in the distribution of $\mathrm{ACE}$ gene I/D genotypes and their allele frequencies between the diabetic nephropathy patients and the controls (Table 1) suggest that this polymorphism is not a risk factor for the development of diabetic nephropathy in the studied population. Given the high incidence of diabetes and hypertension in Punjabi population it is safe to presume that either there are other genetic and environmental factors than ACE gene that predispose such patients to ESRD or the genes implicated in the etiology of diabetic nephropathy might be masking the effect of ACE gene. These observations find support in the work of Tamaki et al. (2002) and Ergen et al. (2004).

In conclusion, our study suggests that the ACE I/D polymorphism is not associated with advanced form of diabetic nephropathy within the North Indian population.

\section{REFERENCES}

Chowdhury TA, Dronsfield MJ, Kumar S, Gough SL, Gibson SP, Khatoon A, MacDonald F, Rowe BR, Dunger DB, Dean JD, Davies SJ, Webber J, Smith PR, Mackin P, Marshall SM, Adu D, Morris PJ, Todd JA, Barnett AH, Boulton AJ, Bain SC 1996. Examination of two genetic polymorphisms within the renin-angiotensin system: no evidence for an association with nephropathy in IDDM. Diabetologia, 39: 1108-1114.

Crisan D, Carr J 2000. Angiotensin I-converting enzyme: Genotype and disease associations. J Mol Diagn, 2: 105-115.

Doria A, Warram JH, Krolewski AS 1994. Genetic predisposition to diabetic nephropathy. Evidence for a role of the angiotensin I-converting enzyme gene. Diabetes, 43: 690-695.

Ergen HA, Hatemi H, Agachan B, Camlica H, Isbir T 2004. Angiotensin-I converting enzyme gene polymorphism in Turkish type 2 diabetic patients. Exp Mol Med, 36: 345-350.

Freedman BI, Yu H, Spray BJ, Rich SS, Rothschild CB, Bowden DW 1997. Genetic linkage analysis of growth factor loci and end-stage renal disease in African Americans. Kidney Int, 51: 819-825.

Gesang L, Liu G, Qiu C, Zhuoma C, Zhuang L, Ren D, Pincuo Z, Chan Y 2002. Angiotensin-converting enzyme gene polymorphism and its association with essential hypertension in a Tibetan population. Hypertens Res, 25: 481-485.

Gupta R, Sarna M, Thanvi J, Rastogi P, Kaul V, Gupta VP 
2004. High prevalence of multiple coronary risk factors in Punjabi Bhatia community: Jaipur heart watch-3. Indian Heart $J$, 56: 646-652.

Hsieh MC, Lin SR, Hsieh TJ, Hsu CH, Chen HC, Shin SJ, Tsai JH 2000. Increased frequency of angiotensinconverting enzyme DD genotype in patients with type II diabetes in Taiwan. Nephrol Dial Transplant, 15: $1008-1013$.

Hubacek JA, Pitha J, Podrapska I, Sochman J, Adamkova V, Lanska V, Poledne R 2000. Insertion/deletion polymorphism in the angiotensin-converting enzyme gene in myocardial infarction survivors. Med Sci Monit, 6: 503-506.

Marre M, Bernadet P, Gallois Y, Savagner F, Guyene TT, Hallab M, Cambien F, Passa P, Alhenc-Gelas F 1994. Relationships between angiotensin I converting enzyme gene polymorphism, plasma levels and diabetic retinal and renal complications. Diabetes, 43: $384-388$

Marre M, Jeunemaitre X, Gallois Y, Rodier M, Chatellier G, Sert C, Dusselier L, Kahal Z, Chaillous L, Halimi S, Muller A, Sackmann H, Bauduceau B, Bled F, Passa P, Alhenc-Gelas F 1997. Contribution of genetic polymorphism in the renin-angiotensin system to the development of renal complications in insulin-dependent diabetes. J Clin Invest, 99: 1585-1595.

Marshall SM 2004. Recent advances in diabetic nephropathy. Postgrad Med J, 80: 624-33.

Miller SA, Dykes DD, Polesky HF 1988. A simple salting out procedure for extracting DNA from human nucleated cells. Nucleic Acids Res, 16: 1215.

Ng DP, Tai BC, Koh D, Tan KW, Chia KS 2005. Angiotensin-I converting enzyme insertion/deletion polymorphism and its association with diabetic nephropathy: a meta-analysis of studies reported between 1994 and 2004 and comprising 14,727 subjects. Diabetologia, 14: (Abstract).

Oh TG, Shin CS, Park KS, Kim SY, Cho BY, Lee HK, Koh CS 1996. Relationships between angiotensin I converting enzyme gene polymorphism and renal complications in Korean IDDM patients. Korean $J$ Intern Med, 11: 133-137.

Pasha MAQ, Khan AP, Kumar R, Ram RB, Grover SK, Srivastava KK, Selvamurthy W, Brahmachari S
2002. Variations in angiotensin-converting enzyme gene insertion/deletion polymorphism in Indian populations of different ethnic origins. J Biosci, 27: $67-70$.

Powrie JK, Watts GF, Ingham JN, Taub NA, Talmud PJ, Shaw KM 1994. Role of glycaemic control in development of microalbuminuria in patients with insulin dependent diabetes. $\mathrm{Br}$ Med J, 309: 16081612 .

Rigat B, Hubert C, Alhenc-Gelas F, Cambien F, Corvol P, Soubrier F 1990. An insertion/deletion polymorphism in the angiotensin I-converting enzyme gene accounting for half the variance of serum enzyme levels. J Clin Inves, 86: 1343-1346.

Rigat B, Hubert C, Corvol P, Soubrier F 1992. PCR detection of the insertion/deletion polymorphism of the human angiotensin converting enzyme gene (DCP1) (dipeptidyl carboxypeptidase 1). Nucleic Acids Res, 20: 1433.

Sakhuja V, Sud K 2003. End-stage renal disease in India and Pakistan: burden of disease and management issues. Kidney Int, Suppl83: S115-S118.

Schmidt S, Ritz E 1997. Angiotensin I converting enzyme gene polymorphism and diabetic nephropathy in type II diabetes. Nephrol Dial Transplant, 12: 3741.

Tamaki S, Nakamura Y, Tsujita Y, Nozaki A, Amamoto K, Kodawaki T, Kita Y, Okamura T, Iwai N, Kinoshita M, Ueshima H 2002. Polymorphism of the angiotensin converting enzyme gene and blood pressure in Japanese general population (the Shigaraki study). Hypertens Res, 25: 843-848.

Tarnow L, Cambien F, Rossing P, Nielsen FS, Hansen BV, Lecerf L, Poirier O, Danilov S, Parving HH 1995. Lack of relationship between an insertion/ deletion polymorphism in the angiotensin Iconverting enzyme gene and diabetic nephropathy and proliferative retinopathy in IDDM patients. Diabetes, 44: 489-494.

Wang Y, Maggie CY, So WY, Tong PCY, Ronald CW, Chow CC, Cockram CS, Chan JCN 2005. Prognostic effect of insertion/deletion polymorphism of the ACE gene on renal and cardiovascular clinical outcomes in Chinese patients with type II diabetes. Diabetes Care, 28: 348-354. 